\title{
Adolescent obesity: An emerging public health crisis in an urban city in South-South Nigeria
}

\author{
Akhimienho Kingsley Irelosen, ${ }^{1}$ Nyong Eno Etim, ${ }^{2}$ Adesina Sunday Babatunde ${ }^{2}$ \\ ${ }^{1}$ Department of Paediatrics, Edo State University, Uzuaire; ${ }^{2}$ Department of Paediatrics, University of Uyo \\ Teaching Hospital, Uyo, Nigeria
}

\begin{abstract}
In Nigeria, a prevalence of obesity of $4.2 \%$ has been reported among adolescents in a study in South-West Nigeria. Studies on the prevalence of obesity among adolescents have yielded different prevalence rates in different parts of the country. The present study was planned to determine the prevalence of obesity amongst apparently healthy adolescents aged 10-18 years in secondary schools in Uyo, as well as determine associated predisposing factors to obesity. This was a cross sectional school-based study of 1,701 adolescents selected by multi-stage sampling technique, carried out between December 2016 to February 2018. It involved measurement of weight, height and waist circumference of the study subjects, as well as administration of pretested questionnaires. Body Mass Index (BMI), Waist Circumference (WC) percentile and waist to height ratio of the subjects were determined. Data was
\end{abstract}

Correspondence: Akhimienho Kingsley Irelosen, Department of Paediatrics, Edo State University, Km 7, Auchi Abuja Road Uzairue, Nigeria.

E-mail:irelosenkingsley@yahoo.com

Key words: Adolescent; obesity; obesogenicity; prevalence; risk factors.

Conflict of interest: The authors declare no conflict of interest.

Availability of data and materials: All data generated or analyzed during this study are included in this published article.

Ethics approval and consent to participate: The Ethics Committee of University of Uyo Teaching Hospital approved this study (UUTH/AD/S/96/VOL XIV/565). The study is conformed with the Helsinki Declaration of 1964, as revised in 2013, concerning human and animal rights. All patients participating in this study signed a written informed consent form for participating in this study.

Informed consent: Written informed consent was obtained from a legally authorized representative(s) for anonymized patient information to be published in this article.

Received for publication: 20 May 2021.

Revision received: 29 June 2021.

Accepted for publication: 29 June 2021.

This work is licensed under a Creative Commons Attribution NonCommercial 4.0 License (CC BY-NC 4.0).

${ }^{\circ}$ Copyright: the Author(s), 2021

Licensee PAGEPress, Italy

Annals of Clinical and Biomedical Research 2021; 2:148

doi:10.4081/acbr.2021.148 analysed using SPSS version 20. Prevalence of obesity was determined and Chi Square was used to determine the relationship between qualitative variables. General obesity was defined as a $\mathrm{BMI} \geq 95^{\text {th }}$ percentile, while central obesity was defined as WtHR $\geq 0.5$ or waist circumference $\geq 90^{\text {th }}$ percentile for age and sex. Prevalence of general obesity was $5.6 \%$ while the prevalence of central obesity was $11.2 \%$ using WC percentile and $9 \%$ using WHtR. This study also revealed higher prevalence of obesity in females, adolescents from monogamous homes, as well as those whose parents are from the upper socio-class. It is recommended that routine measurement of the indices of adiposity and public health enlightenment measures aimed at reducing the burden of obesity amongst adolescents in Uyo be encouraged by public health authorities. The physicians should be encouraged to measure the indices of adiposity during consultations.

\section{Introduction}

Obesity is an emerging and important paediatric public health problem associated with risks of complications in childhood and increased morbidity and mortality throughout adult life. ${ }^{1}$ In children, Obesity is defined as a Body Mass Index $(\mathrm{BMI}) \geq 95^{\text {th }}$ percentile for age and sex, or a waist circumference $\geq 90^{\text {th }}$ percentile for age/sex. ${ }^{1}$ It can also be defined as a waist to height ratio greater than $0.5 .^{1}$ The main burden of obesity as a public health concern is the increased morbidity from ischaemic heart disease, heart attack and stroke in adult life. ${ }^{2}$ These morbidities if not treated can lead to death. The pre-diabetes rate in overweight adolescents is 2.6 times higher than that of normal weight adolescents. ${ }^{3}$ Overweight and obese children also have increased risks of asthma, obstructive sleep apnea, musculoskeletal, emotional, behavioral and orthopedic problems. ${ }^{4-7}$

Childhood obesity can be caused by a range of factors which may be genetic or environmental. ${ }^{8}$ The obesogenecity of an environment is thus the sum of all the factors inherent within it that predispose to obesity. ${ }^{9}$ These factors include lack of exclusive breastfeeding, sedentary behavior, consumption of high calorigenic food, increased maternal pregravid weight, amongst others. ${ }^{10-13}$

There is a growing global obesity epidemic with wide variations in secular trends amongst various countries. ${ }^{14}$ In the United States of America, prevalence of $20.5 \%$ was reported amongst adolescents ${ }^{15}$ while in a developing country like Ghana, prevalence of $0.8 \%$ has been reported in Kumasi region. ${ }^{16}$ In Nigeria, the national prevalence of obesity is unknown. ${ }^{17}$ However, a study done in South-Western Nigeria revealed a prevalence of $4.2 \%$ amongst adolescents. ${ }^{18}$

This study therefore is a prevalence study that addresses the burden of obesity (both general and central) amongst adolescents in a city in South-South Nigeria. It also identifies some factors peculiar to adolescent obesity in this region. 


\section{Materials and Methods}

This study was conducted amongst adolescents attending public and private schools in Uyo, Akwa Ibom State between December 2016 and February 2018. Uyo is the capital of Akwa Ibom State and has an estimated population of 847,500 a total area of $362 \mathrm{~km}^{2} .{ }^{19}$ The people are predominantly civil servants, farmers, traders and artisans. ${ }^{20}$ The study was conducted amongst adolescents between 10-18years old. Sample size was determined using the Fisher's formula, with a population prevalence (from a previous study) of $4.2 \%$, and a degree of precision of $1 \% .{ }^{18,21,22}$

Thus, the total sample size was 1701 .

Ethical approval was obtained from the university of Uyo Teaching Hospital. Approval was obtained from the State Ministry of Education and permission obtained from the school principals. Written informed consent was obtained from the parents and assent from the student.

A total of 12 schools ( 6 public and 6 privates) were selected for the study.

Weight of the participants was measured to the nearest $0.10 \mathrm{~kg}$.

6 AA battery powered digital scale (Seca ${ }^{\circledR} 877$ class III) was used to measure the weight. ${ }^{23}$ Height was measured to the nearest $0.10 \mathrm{~cm}$ using a portable collapsible stadiometer $\left(\mathrm{Seca}{ }^{\circledR}\right.$ Leicester portable height measure). Measurements were taken at the Frankfurt plane to avoid parallax error. ${ }^{23}$ Waist circumference was measured to the nearest $0.10 \mathrm{~cm}$ using a flexible non elastic tape (Seca ${ }^{\circledR}$ 201). The tape was placed parallel to the floor, midway between the last palpable rib and the top of the iliac crest. Each student was also made to fill a pre-texted questionnaire. The socioeconomic class of each participant was determined using the Oyedeji's classification. BMI was calculated using the formula $\mathrm{BMI}=$ Weight $(\mathrm{kg}) / \mathrm{Height} 2(\mathrm{~m} 2)$

Waist to Height ratio (WHtR) was calculated using the formula Waist Circumference $(\mathrm{cm}) \div$ Height $(\mathrm{cm})$. Corresponding percentiles for BMI and waist circumference were obtained from the respective percentile charts ( $\mathrm{CDC} / \mathrm{WHO}$ respectively).

All Data obtained were arranged into tables and analyzed using the statistical package for the Social Sciences (SPSS) Version 20.
The prevalence of Obesity was determined as $\mathrm{BMI} \geq 95^{\mathrm{TH}}$ percentile (general obesity) ${ }^{24}$ or $\mathrm{WHtR} \geq 0.5 / \mathrm{WC}^{25}$ percentile $\geq 90^{\text {th }}$ percentile ${ }^{26}$ for central adiposity. Statistical significance was set at $\mathrm{p}$ values $<0.05$ at $95 \%$ confidence interval.

Table 1, Figures 1 and 2 show the sociodemographic characteristics of the participants.

A total of 1701 children were studied. Majority of the participants were less than 14 years old (580 or $34.1 \%$ ). The least number of participants were between 16-18 years of age (544 or 32\%).

The male to female ratio of the participants was $1: 1.4$. The highest numbers of participants in the study were Ibibios $(1,385$ or $81.4 \%$ ). Hausas had the least number of participants (10 or $0.6 \%)$ Most of the participants were Christians (99.5\%) while just a few were Muslims $(0.5 \%)$.

Table 1. Demographic characteristics of participants.

\begin{tabular}{lc} 
& N \\
Age group & \\
$10-<14$ years & 580 \\
$14-<16$ years & 577 \\
$16-18$ years & 544 \\
Sex & \\
Male & 720 \\
Female & 981 \\
Religion & \\
Christianity & 1692 \\
Islam & 9 \\
Others & 0 \\
Nature of Family & \\
Monogamous & 1457 \\
Polygamous & 244 \\
\hline Family setting & \\
Married & 1450 \\
Divorced & 90 \\
Single & 51 \\
Widowed & 110 \\
Total & $1701(100)$ \\
\hline
\end{tabular}

Table 3. Socio-demographic status in relation to the prevalence of obesity among adolescents using BMI percentile.

\begin{tabular}{|c|c|c|c|c|}
\hline & $\begin{array}{l}\text { Obese } \\
\text { N (\%) }\end{array}$ & $\begin{array}{c}\text { Non-Obese } \\
\text { N (\%) }\end{array}$ & $\begin{array}{l}\text { Total } \\
\text { N (\%) }\end{array}$ & p \\
\hline $\begin{array}{l}\text { Age group } \\
10-<14 \text { years } \\
14-<16 \text { years } \\
16-18 \text { years }\end{array}$ & $\begin{array}{c}35(6) \\
34(5.9) \\
27(5)\end{array}$ & $\begin{array}{c}545(94) \\
543(94.1) \\
517(95)\end{array}$ & $\begin{array}{c}580(34.1) \\
577(33.9) \\
544(32)\end{array}$ & 0.7 \\
\hline $\begin{array}{l}\text { Sex } \\
\text { Male } \\
\text { Female }\end{array}$ & $\begin{array}{l}19(2.6) \\
77(7.8)\end{array}$ & $\begin{array}{l}701(97.4) \\
904(92.2)\end{array}$ & $\begin{array}{l}720(42.3) \\
981(57.7)\end{array}$ & $0.001^{*}$ \\
\hline $\begin{array}{l}\text { SEC } \\
\text { Upper class } \\
\text { Middle class } \\
\text { Lower class }\end{array}$ & $\begin{array}{l}71(7.1) \\
11(2.4) \\
14(5.5)\end{array}$ & $\begin{array}{l}925(92.9) \\
441(97.6) \\
239(94.5)\end{array}$ & $\begin{array}{l}996(58.6) \\
452(26.6) \\
253(14.9)\end{array}$ & $0.002^{*}$ \\
\hline $\begin{array}{l}\text { Nature of Family } \\
\text { Monogamous } \\
\text { Polygamous } \\
\text { Family setting } \\
\text { Married } \\
\text { Divorced } \\
\text { Single } \\
\text { Widowed }\end{array}$ & $\begin{array}{c}89(6.1) \\
7(2.9) \\
\\
80(5.5) \\
7(7.8) \\
5(9.8) \\
4(3.6)\end{array}$ & $\begin{array}{c}1368(93.9) \\
237(97.1) \\
\\
1370(94.5) \\
83(92.2) \\
46(90.2) \\
106(96.4)\end{array}$ & $\begin{array}{c}1457(85.7) \\
244(14.3) \\
1450(85.2) \\
90(5.3) \\
51(3.0) \\
110(6.5)\end{array}$ & $0.04^{*}$ \\
\hline Total & - & - & $1701(100)$ & \\
\hline
\end{tabular}


Majority of the participants were in Social Class 2 (516 or $30.3 \%$ ); while Social Class 5 had the least number of participants (37 or $2.2 \%$ ). Most of the participants $(1,457$ or $85.7 \%$ ) were from monogamous homes. Adolescents whose parents were still married had the largest number of participants $(1,457$ or $85.7 \%)$, while those from single parents had the least number of participants (51 or $3 \%$ ).

Table 2 shows the prevalence of obesity using the three parameters selected.

The prevalence of general obesity was $5.6 \%$ while that of central obesity was $11.2 \%$ using WC percentile and $9 \%$ using WHtR.

Table 3 shows the relationship between the sociodemographic characteristics of the participants and their BMI percentile. Adolescents between 10 to $<14$ years had the highest prevalence of general obesity $(6 \%)$ compared to the other age groups. Females had the highest prevalence of general obesity compared to males $(7.8 \%$ cf $2.6 \%)$. This was statistically significant $(\mathrm{p}=0.001)$. Adolescents whose parents were from the upper social class had the highest prevalence of general obesity (7.1\%). This was statistically significant $(\mathrm{p}=0.002)$. In addition, general adiposity was more prevalent amongst adolescents from monogamous homes (6.1\%). This was statistically significant $(\mathrm{p}=0.04)$.

Tables 4 and 5 show the relationship between sociodemographic factors and the measures of central adiposity. The prevalence of central obesity was highest in adolescents between 1618 years (14.3\% and $11.2 \%$ respectively). The prevalence of obesity was higher in females compared to males $(13.6 \%$ cf $7.9 \%$; $12.6 \%$ cf $4 \%$ for WC percentile and WHtR respectively. This was statistically significant $(\mathrm{p}=0.001)$. Adolescents from the upper social class had the highest prevalence of central obesity $(13.6 \%$ and $10.1 \%$ for WC percentile and WHtR respectively). Why this was significant for WC percentile $(\mathrm{p}=0.001)$, it was not significant for WHtR ( $\mathrm{p}=0.14)$. The prevalence of central obesity was higher among adolescents from monogamous homes (14.4\% and 9.5\% respectively). This was not statistically significant $(\mathrm{p}=0.55$ and 0.07 respectively).

\section{Discussion}

The overall prevalence of general obesity in this study was $5.6 \%$ while the prevalence of Central Obesity was $11.2 \%$ using WC percentile and 9\% using WHtR. The Prevalence of central obesity was higher than the prevalence of general obesity. This is an agreement with a study which showed that WC measurement alone or in combination with height is a more sensitive measure for identifying obesity compared to BMI. ${ }^{27}$ The $5.6 \%$ obtained as the prevalence of general obesity in this study is much lower than the $20.5 \%$ reported by Ogden et al. amongst American adolescents. ${ }^{15}$

The lower prevalence of general obesity in this study may be due to difference in genetic make-up between both population and partly due to the fact that adolescents in our setting are exposed to less calorigenic diets compared to those in the USA.

The prevalence of Obesity using BMI is very similar to the $5.7 \%$ reported by Rohilla et al. amongst adolescents in India. ${ }^{28}$ Similarities in the age group of adolescents studied may explain this despite differences in the study environment.

The prevalence of general obesity obtained in this study is much higher than that reported in some studies in Ota and Ile-Ife, South-West Nigeria (3.4\% and 4.2\%), ${ }^{18,29}$ as well as Benue, NorthCentral Nigeria $(1.8 \%){ }^{30}$ This difference may be due to the fact that Uyo is a more Urban setting compared to these cities; and has more eateries which have contributed to the increased obeso- genecity of Uyo compared to these areas. The prevalence of Central obesity obtained from this study is high, and higher than the $10.6 \%$ and $8.4 \%$ reported by Castro et al and Park et al, in Brazilian and Korean adolescents respectively. ${ }^{31,32}$ The difference in prevalence may be due to the sample size used in this study compared to these other two mentioned. However, the prevalence of central obesity is much lower than the $24.5 \%$ reported by Senbanjo and Oshikoya amongst adolescents in Abeokuta. ${ }^{33}$ This is because Senbanjo and Oshikoya used the $75^{\text {th }}$ percentile cut-off (which included adolescents between the $75^{\text {th }}$ and $90^{\text {th }}$ percentile).

The prevalence of central obesity using WHTR is very similar to the $9.1 \%$ reported by Kromeyer-Hauschild et al. amongst German adolescents. ${ }^{34}$ Similarity in the age group of respondents could explain this.

Table 2. Prevalence of obesity in adolescents using body mass index, waist to height ratio, and waist circumference percentile.

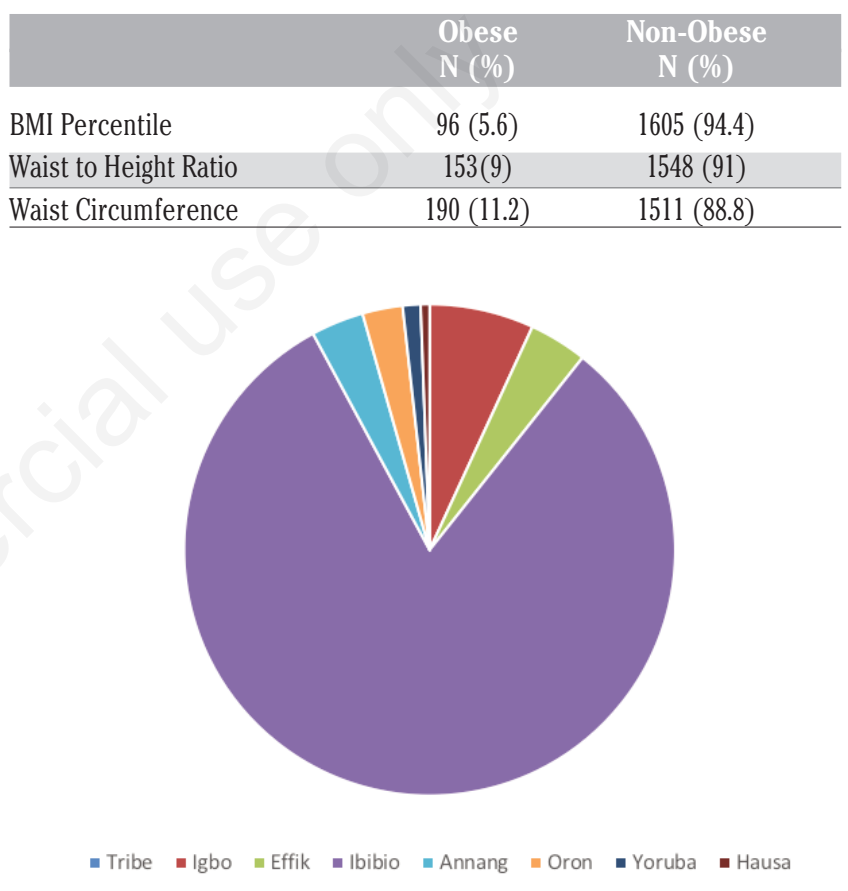

Figure 1. Ethnic groups of participants.

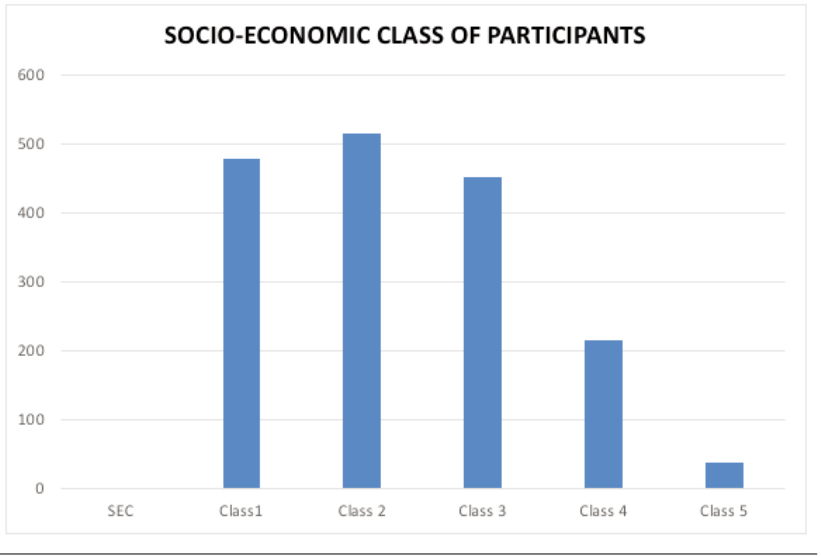

Figure 2. Socio-economic class of participants. 
This study shows that all forms of obesity have higher prevalence amongst adolescents in the upper socio-economic class. Alkali et al. reported comparable findings amongst adolescent in Gombe ${ }^{35}$ However, this is contrast to what is obtainable in developed nations like the US where obesity is commoner amongst the low socio-economic class. ${ }^{36}$ The reason for this may be because adolescents in our environment from high socio-economic class are more likely to consume junk food and engage in less degree of physical activities as a manifestation of affluence thus increasing the risk of developing obesity.

The result of this study also shows that all forms of obesity are commoner in females, and there is a significant association between gender and obesity. Similar findings have been reported in other studies in Nigeria and some parts of the world. ${ }^{37-40}$ This may be explained by the fact that there is a sex specific gene (Lysophospholipase-like-1 gene) which is expressed solely in females and is known to cause increased distribution in females. ${ }^{41}$

A significant association was found between obesity and family setting with general obesity being commoner amongst adolescents from monogamous homes. The reason for this may be due to the fact that monogamous setting may have fewer children struggling for food, thus making food more readily available. ${ }^{42}$

The pattern of general and central adiposity differs in adolescents with central obesity being commoner amongst the adolescents studied.

Table 4. Social status in relation to the prevalence of obesity among adolescents using waist circumference percentile.

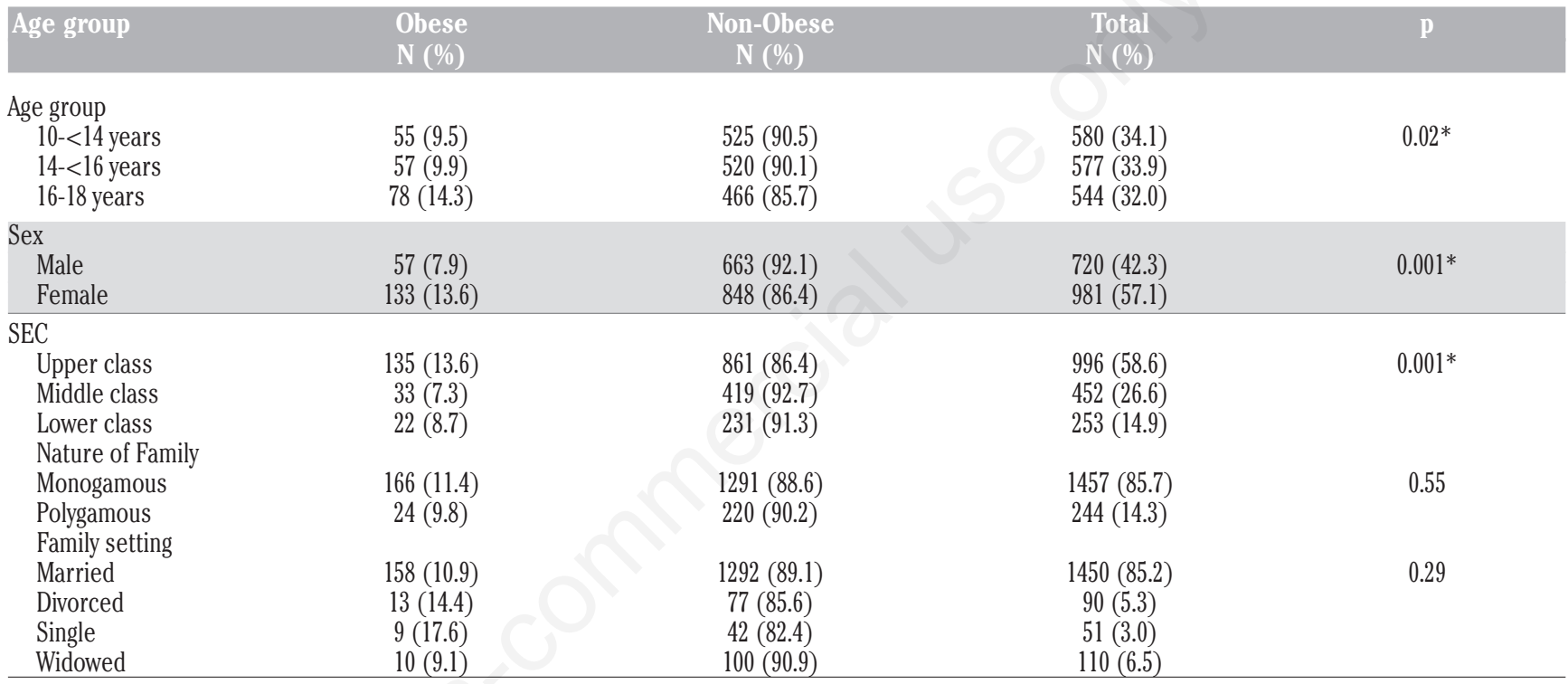

Table 5. Social status in relation to the prevalence of obesity among adolescents using waist to height ratio.

\begin{tabular}{|c|c|c|c|c|}
\hline Obese & $\begin{array}{c}\text { Non-Obese } \\
\text { N }(\%)\end{array}$ & $\begin{array}{l}\text { Total } \\
\text { N (\%) }\end{array}$ & $\begin{array}{c}\text { p } \\
\text { N }(\%)\end{array}$ & \\
\hline $\begin{array}{l}\text { Age group } \\
10-<14 \text { years } \\
14-<16 \text { years } \\
16-18 \text { years }\end{array}$ & $\begin{array}{c}42(7.7) \\
46(8) \\
65(11.2)\end{array}$ & $\begin{array}{c}502(92.3) \\
531(92) \\
515(88.8)\end{array}$ & $\begin{array}{l}544(32.0) \\
577(33.9) \\
580(34.1)\end{array}$ & 0.07 \\
\hline $\begin{array}{l}\text { Sex } \\
\text { Male } \\
\text { Female }\end{array}$ & $\begin{array}{c}29(4) \\
124(12.6)\end{array}$ & $\begin{array}{c}691(96) \\
857(87.4)\end{array}$ & $\begin{array}{c}720(4.3) \\
981(57.7)\end{array}$ & $0.001^{*}$ \\
\hline $\begin{array}{l}\text { SEC } \\
\text { Upper class } \\
\text { Middle class } \\
\text { Lower class } \\
\text { Nature of Family } \\
\text { Monogamous } \\
\text { Polygamous } \\
\text { Family setting } \\
\text { Married } \\
\text { Divorced } \\
\text { Single } \\
\text { Widowed }\end{array}$ & $\begin{array}{c}101(10.1) \\
32(7.1) \\
20(7.9) \\
\\
139(9.5) \\
14(5.7) \\
\\
126(8.7) \\
8(8.9) \\
9(17.6) \\
10(9.1)\end{array}$ & $\begin{array}{c}895(89.9) \\
420(92.9) \\
233(92.1) \\
\\
1318(90.5) \\
230(94.4) \\
\\
1324(91.3) \\
82(91.1) \\
42(82.4) \\
100(90.9)\end{array}$ & $\begin{array}{c}996(58.6) \\
452(26.6) \\
253(14.9) \\
\\
1457(85.7) \\
244(14.3) \\
\\
1450(85.2) \\
90(5.3) \\
51(3.0) \\
110(6.5)\end{array}$ & 0.07 \\
\hline
\end{tabular}




\section{Conclusions}

This study has shown that obesity is becoming a public health challenge in our environment. Regular measurement of the indices of adiposity is necessary to stem this tide. Given the significant relationship between diseases, the importance of this cannot be over-emphasized.

\section{References}

1. Gahagan S. Overweight and obesity. In Kliegman RM, Stanton BF, St Gene III JW, et al. (eds) Nelson Textbook of Paediatrics. 19th edition. Philadelphia: Elsevier; 2011; 707-24.

2. Schneider HJ, Friederich N, Klitsche J, et al. The Predictive Value of different measures of obesity for incident cardiovascular events and mortlity. J Clin Endocrinol Metab 2010;95:1777-85.

3. Chaoying Li, Ford SE, Zhao G, Mokdad A. Prevalence of Prediabetes and its association with clustering of cardiometabolic risk factors and hyperinsulinaemia among US Adolescents. Diabetes Care 2009;32:342-49.

4. Egan K, Ettiger A, Bracken M. Childhood BMI and Subsequent Physician diagnosed Asthma: A systematic review and meta-analysis of prospective cohort studies. BMC Pediatrics 2013:13:121-33.

5. Narang I, Matthew JL. Childhood obesity ad obstructive sleep apnea. J Nutr Metab 2012:2012:8.

6. Griffiths LJ, Dezateux C, Hill AJ. Self Esteem and Quality of life in obese children and adolescent: A systematic review. Int J of Paediatric Obes 2010;5:282-304.

7. Daniels SR. Complications of Obesity in children and adolescents. Int J Obes (Lond) 2009;33:60-5.

8. Ebbeling CB, Pawlak DB, Ludwig DS. Childhood obesity: Public health crisis, common sense care. Lancet 2002;360:47382.

9. McBride D. Childhood obesity. Practice Nurse 2010;39:40-5.

10. Metzer MW, McDade TW. Breastfeeding as obesity prevention in the United States: A sibling model. AM J Hum Biol 2010;22:291-6.

11. Mitchell JA, Mattocks C, Ness AR, et al. Sedentary behaviour and obesity in a large cohort of children. Obesity 2009; 17:1596-02.

12. Malik VS, Schulze MB, Hu FB. Intake of Sugar sweetened beverages and weight gain: A systematic review AM J Clin Nutr 2006;84:274-88.

13. Catalano PM, Farell K, Thomas A, et al. Perinatal risk factors for childhood obesity and metabolic dysregulation AM J Clin Nutr 2009;90:1303-13.

14. Wang Y, Lobstein T. Worldwide trends in childhood overweight and obesity. Int J of Paediatr Obes 2006;1:11-25.

15. Ogden CL, Flegal KM, Caroll MD, Johnson CL. Prevalence and trends in overweight among US Children and Adolescents 1999-2000. JAMA 2002;288:1728-32.

16. Kumah DB, Akuffo KO, Abaka-Cann JE, Osae EA. Prevalence of Overweight and Obesity among students in the Kumasi Metropolis. J Nutr Metab 2015:2015:61320c.

17. Udoh SB, Iyanam V. Overweight, obesity and underweight profile among adolescent secondary school students in Uyo, South-South Nigeria. NJFP 2016;7:17-26.

18. Sabajeh AO, Ojofeitimi EO. Prevalence of obesity among ado- lescents in Ile-Ife, Osun State, Nigeria using BMI and waisthip-ratio: a comparative study. Niger Med J 2013;54:153-6.

19. Summary of the two LGAs, Uyo and Itu LGA as per Federal Republic of Nigeria official gazette. (15th May 2007) legal notice on the publication of the details of the breakdown of the national and state provisional totals 2006 census. Accessed $15 / 6 / 16$

20. Akwa Ibom State Government. Akwa Ibom State: geographical location. 2012. Accessed: 6/10/2017. Available from: https://www.aksgonline.com/about_geography.html

21. Araoye MO. Sample size determination. In: Araoye MO. Research methodology for health and social sciences Ilorin. Nathadex; 2003.

22. Naung L, Winn T, Rush BN. Practical issues in calculating sample size for prevalence studies. Arch Orofac Sci 2006;1:914.

23. World Health Organization. Physical station: the use and interpretation of anthropometry; a report of a WHO expert committee serves no 854. Geneva: 1995. Accessed: 7/7/16. Available from: https://apps.who.int/iris/handle/10665/37003

24. Kuczmarski RJ, Ogden CL, Grummer-Strawn LM, Flegal KM, Guo SS, Wei R, Mei Z, Curtin LR, Roche AF, Johnson CL. CDC growth charts: United States. Adv Data 2000;314:1-27.

25. Browning LM, Hsieh SD, Ashwell M. A systematic review of Waist to height ratio as a screening tool for the prediction of Cardiovascular disease and diabetes: $O .5$ could be a suitable global value. Nutr Pos Rev 2010;23:247-61.

26. Evsa MA, Dai S, Mihalopoulos NL, et al. Trajectories of Fat mass index, fat free mass index and waist circumference in children. AM J Prev Med 2009;37:S34-9.

27. Price GM, Maning R, Breeze E, et al. Weight, shape and mortality risk in older persons, elevated WHTR, not BMI is associated with a higher risk of death. AM J Clin Nutr 2006;84:449-60.

28. Rohilla R, Rajput M, Rohilla J, et al. Prevalence of overweight/obesity among adolescents in an urban city of North India. J Fam Med Primary CARE 2014,3:404.

29. Igbokwe O, Adimorah G, Ikefuna A, et al. Sociodemographic determinants of malnutrition amongst primary school aged children in Enugu, Nigeria. PAMJ 2017:28:248.

30. Musa DI, Toriola AL, Monyeki MA, Lawal B. Prevalence of childhood and adolescent overweight and obesity in Benue state Nigeria. J Trop Med Int Health 2012;17:1369-75.

31. Castro JAC, Nunes HEG, Solva DAS. Prevalence of Obesity in Adolescents: Assoication between sociodemographic factors and lifestyle. Rev Paul Pediatr 2016;34:343-51.

32. Palk J, Holmes DC, Mendoza JA, et al. Prevalence of metabolic syndrome and obesity in adolescents aged 12-19 years, comparison between the United States and Korea. J Korean Med Sci 2010;25:75-82.

33. Senbanjo IO, Orlukoya KA. Obesity and blood pressure levels of adolescents in Abeokuta, Nigeria. Cardiovasc Topics 2012;23:260-4

34. Kromeyer-Hauschild K, Neuhauser H, Schaffrath Rosario A, Schienkiewitz A. Abdominal obesity in German adolescents defined by waist-to-height ratio and its association to elevated blood pressure: the KiGGS study. Obes Facts 2013;6:165-75.

35. Alkali YS, Ambe JP, Sabin M, Zacharin M. Socioeconomic status, lifestyle and childhood obesity in Gombe. NJP 2015;42:107-10.

36. Wang Y. Disparities in paediatric obesity in the United States. Adv Nutr 2011;2:23-31.

37. Oera JA, Adejuyibe O. Fat mass percentage body mass index 
and mid upper arm circumference in a healthy population of Nigerian children. J Trop Pediatr 1997;43:13-9.

38. Akesode FA, Ajibode HA. Prevalence of obesity among Nigerian secondary school children in Abeokuta. Soc Sci Med 1983:107-11.

39. Ahmad MM, Ahmed H, Airede K. Body Mass Index among school adolescents in Sokoto; North Western Nigeria. Sahel Med J 2013;16:5-9.

40. Rossouw HA, Grant CC Viljoen M. Overweight and obesity in children and adolescents: the South African problem. S Afri J
Sci 2012;108.

41. Zillikens MC, Yazdanpanah M, Pardo LM, et al. Sex Specific genetic effects influence variations in body composition. Diabetologia 2008;51:2233-4.

42. Ojofetimi EO, Olugbenga-Bello AI, Adekanle DA, Adeomi AA. Patterns and determinants of obesity among adolescents females in private and public schools in the Olorunda local government area of Osun State, Nigeria: A comparative study. J Pub Health Afr 2011;2:45-9. 